\title{
PREFERENSI PEMANFAATAN RUANG PUBLIK DI RUMAH SUSUN SEWA MARISO DI MAKASSAR
}

\author{
Ratriana Said Bunawardi*1, Burhanuddin Amin ${ }^{2}$ \\ Universitas Islam Negeri Alauddin, Makassar ${ }^{1,2}$ \\ e-mail: *1ratriana@gmail.com, ${ }^{2}$ burhanuddin.amin@uin-alauddin.ac.id
}

\begin{abstract}
Abstrak_ Rumah susun sewa merupakan rumah vertikal yang dirancang untuk orang berpenghasilan rendah, dan merupakan respon atas tingginya permintaan tempat tinggal yang layak. Rumah susun ini juga diharapkan dapat lebih efisien dalam penggunaan lahan dan mampu mengurangi jumlah permukiman kumuh di daerah perkotaan. Fenomena yang terlihat pada rumah susun sewa Mariso, dimana preferensi penghuni dalam memanfaatkan ruang-ruang publik yang tidak sesuai dengan rencana fungsi awal ruang. Adanya konflik spasial berasal dari aktivitas dan mobilitas penghuni mengakibatkan terjadi invasi pada sebagian ruang publik. Beberapa ruang melebihi fungsi dan tujuan dasarnya, sementara ruang lain dimanfaatkan secara tidak sesuai dengan fungsi desain awalnya. Studi komprehensif dilakukan untuk mengenali karakter penghuni beserta latar belakang pekerjaan, pendapatan dan pendidikan mereka sehubungan dengan perilaku mereka terhadap ruang publik dan pemanfaatannya. Metode tracing (person centered map) digunakan pada penelitian ini. Sampel berupa penghuni rumah susun Mariso dipilih berdasarkan karakteristik penghuni seperti usia, gender dan pekerjaan untuk mengungkapkan aktivitas dan interaksi sehari-hari. Hasil penelitian ini ditemukan bahwa penghuni berpenghasilan rendah lebih memilih untuk terlibat dalam interaksi sosial secara informal. Kegiatan pribadi tertentu dilakukan di ruang publik dan bukan di unit huniannya dan dalam banyak kesempatan, aktivitas pribadi dilakukan secara berkelompok penghuni sebagai bagian dari rutinitas sehari-hari mereka. Koridor yang didesain sebagai jalur penghubung antar unit hunian mendapat beban yang berlebih karena intervensi aktivitas pribadi. Sebaliknya, beberapa ruang komunal tampaknya ditinggalkan oleh karena berbagai alasan. Fenomena adanya kegiatan pribadi di ruang komunal telah menurunkan kualitas hunian, dan menjadi kawasan kumuh vertikal lainnya di dalam wilayah perkotaan. Hasil studi harus dipertimbangkan, dievaluasi dan dirujuk untuk desain ruang publik lebih lanjut dan lebih baik pada tipe perumahan seperti itu
\end{abstract}

Kata kunci: Preferensi penghuni, Rumah Susun, Ruang Publik

\begin{abstract}
Rental flat is a vertical house designed for low-income people and in response to the high demand for housing. Its also expected to be more efficient in land use and will reduce the number of slums in urban areas. The phenomenon is seen in the Mariso flats, where the preferences of residents in utilizing public spaces are not in accordance with the initial function of space. Spatial conflict arises from the activities and mobility of residents resulting in an invasion of some public spaces. Some spaces exceed their basic functions and objectives, while other spaces are not used according to their original design functions. A comprehensive study conducted to identify the occupant background, job, income and education in connection with their behavior towards public space and its utilization. The research method is accomplished by mapping the behaviors such as place center map. Samples of Residents selected based on characteristics such as age, gender and work to expose the activities and daily interactions. The results of this study found that low-income residents prefer informal social
\end{abstract}

\footnotetext{
${ }^{1}$ Universitas Islam Negeri Alauddin, Makassar

${ }^{2}$ Universitas Islam Negeri Alauddin, Makassar
} 
interactions. Certain private activities are carried out in public spaces and not in their residential units. On several occasions, private activity conducted in groups of residents as part of their daily routine. Corridors that are designed as a connecting line between residential units are overloaded due to personal activity interventions. Conversely, some communal spaces seem abandoned for various reasons. The phenomenon of private activities in communal spaces has reduced the quality of residents, and become another vertical slum in the urban area. Study results must be considered, evaluated and referred for further and better design of public space. in such types of housing.

Keywords: Residence Preference; Flats; Public Space.

\section{PENDAHULUAN}

Rumah susun ini dibangun sebagai respon pemerintah menjawab tingginya kebutuhan akan masyarakat akan tempat tinggal yang layak dan sebagai efisiensi lahan agar area slum di ibukota dapat dikurangi. Data Kementerian PUPR mencatat angka backlog pada 2015 mencapai 7,6 juta unit dan Akumulasi backlog di Indonesia berkisar 800 ribu per tahun. Sejauh ini pengembangan pola hunian berbasis komunitas bertingkat ini dianggap mampu memberikan solusi dari segi kuantitas dengan signifikan (Siregar 2013).

Membangun sebuah hunian adalah merupakan kegiatan berbudaya, cerminan perwujudan nilai-nilai sosial yang dianut oleh penghuninya. Penghuni yang menempatinya pun memiliki berbagai latar belakang yang berbeda dan tidak serta merta menyesuaikan diri dengan pola yang telah ditetapkan. Beragam persepsi yang pro dan kontra muncul baik sebelum menghuni dan setelah menghuni vertikal house tersebut. Akan tetapi pemerintah selalu mencoba menanamkan mindset yang positif agar tinggal di rumah susun dapat diterima kalangan masyarakat.

Fenomena yang sering terjadi dimana penghuni dalam beradaptasi selalu berusaha mencoba memindahkan pola kehidupannya dari landed house (rumah horisontal) ke hunian vertikal. Ada anggapan bahwa jika menempati rumah susun, maka segala kegiatan akan menjadi terbatas. Hal ini kerena keterbatasan teritori ini, sehingga mendorong penghuni memanfaatkan ruang publik menjadi ruang pribadi. Hal ini kerap terjadi pada teras atau balkon rumah, selasar, hall, ruang tangga dan lain-lain. Anggapan keterbatasan teritorial ini kadang menyebabkan banyak terjadinya overlapping ataupun perubahan fungsi antara hunian pribadi dan ruang publik. Kenyataan lain yang ada, pada ruang-ruang publik diatas juga sering dimanfaatkan untuk berkumpul sesama warga rumah susun, sehingga timbul kendala-kendala seperti kebisingan, kurang tertib, bahkan ruang bersama tersebut menjadi sulit untuk diakses publik. Meskipun berbagai jenis tipe rumah susun telah tersedia, namum belum mampu menjawab/memenuhi tingkat kepuasan akan kebutuhan ruang bagi penghuninya. Banyak perubahan fungsi pada ruang publik yang terjadi, mengakibatkan terjadinya penurunan kualitas fisik ruang dan kualitas kehidupan penghuninya sendiri. Lingkungan unit hunian menjadi tidak teratur dan kembali kumuh.

Seiring dengan adanya upaya percepatan dan peningkatan pembangunan rumah susun, maka harus juga diimbangi dengan peningkatan kualitas hidup. Maka faktor persepsi, karakteristik budaya dan perilaku penghuni harus menjadi pertimbangan utama. Guna menghindari segala bentuk akses sindroma rumah susun, maka disamping perlu adanya pendekatan asas keterjangkauan, perlu pula pendekatan dari segi sosial budaya dan psikologi.

Ruang publik merupakan salah satu bagian kebutuhan utama penghuni rumah susun. Ruang publik secara umum dapat diinterpretasikan sebagai ruang milik bersama (Said and Alfiah 2017). 
Ruang ini bisa berada di dalam unit bangunan atau di antara blok bangunan, biasanya berfungsi sebagai ruang komunal dan untuk mengembangkan kehidupan masyarakat. Area ini juga dapat berfungsi sebagai ruang pengikat untuk interaksi sosial antar bangunan dan unit.

Carr et al (1992) menyatakan bahwa "public space can be interpreted as collectively owned space, area for community functional activities and ritual bonds, either for daily routines or celebrations". Carr juga mengungkapkan tiga kualitas utama sebuah ruang publik yaitu, tanggap (responsive), berarti bahwa ruang tersebut dirancang dan dikelola dengan mempertimbangkan kepentingan para penggunanya. Demokratis (democratic) yang berarti bahwa hak para pengguna ruang publik tersebut terlindungi, pengguna ruang publik bebas berekspresi dalam ruang tersebut, namun tetap memiliki batasan tertentu karena dalam penggunaan ruang bersama perlu ada toleransi diantara para pengguna ruang dan bermakna (meaningful) berarti mencakup adanya ikatan emosional antara ruang tersebut dengan kehidupan para penggunanya.

Menurut Lumbantoruan, Faqih, and Antaryama (2010), karena ukuran unit yang terbatas untuk beberapa penghuni di rumah susun sederhana, memaksa mereka untuk mengubah komposisi unit mereka dan bahkan menggunakan ruang publik yang tidak sesuai dengan fungsi awalnya; sebuah kondisi yang dapat memicu konflik spasial sebagai pemanfaatan ruang publik sebagai kawasan properti pribadi.Ruang publik juga sering dianggap sebagai ruang yang diperebutkan; tempat di mana oposisi, konfrontasi, perlawanan dan subversi dapat dimainkan di atas 'hak atas ruang' (Holland et al. 2007). Dalam kasus lain, terkadang penghuni menggabungkan fungsi sosial lain dari ruang publik, misalnya di koridor yang terutama ditujukan sebagai sarana gerak mobilitas, sirkulasi dan interaksi ringan, namun pada kenyataannya area ini juga menjadi tempat menjemur, bersantai, ngobrol, dan sebagainya. Terkadang furnitur tambahan diletakkan di area sirkulasi dengan alasan keinginan untuk mengekspresikan diri atau membentuk ruang interaksi sosial baru, namun hal ini justru bisa merintangi dan membebani area yang terletak di depan unit hunian ruangan. Realitas ini turut menyumbang terjadinya penurunan kualitas lingkungan rumah susun sewa dan penurunan fungsi ruang Prayitno (1999), juga mengungkapkan bahwa koridor yang terdapat baik pada lantai dasar atau di lantai atas adalah bagian dari ruang bersama.Konsep koridor yang didefinisikan ulang menjadi tidak hanya untuk ruang 'berpindah', tapi juga untuk tempat duduk.

Oleh karena berbagai teori tersebut, tujuan dari penelitian ini adalah untuk mengetahui preferensi pemanfaatan ruang-ruang publik di rumah susun sewa yang diperuntukkan bagi masyarakat berpenghasilan rendah, dan mengetahui perbedaan sosial interaksi dari kelompok pengguna dan pengaruhnya terhadap pemanfaatan ruang-ruang.

\section{METODE}

Metode penelitian yang digunakan adalah dengan adalah dengan metoda deskriptif kualitatif. Metode ini menganalisis dengan cara memaparkan keadaan objek, dikaji menggunakan data primer dan sekunder. Data primer didapatkan dengan melakukan survey pemetaan perilaku penghuni (person centered map) dan aktivitasnya sehari-hari, wawancara terhadap penghuni dan dokumentasi.Survey lokasi dilakukan pada bulan Juni 2017. Responden dipilih berdasarkan kriteria masa bermukim Data sekunder bersumber dari kajian literatur dan studi banding dengan hunian yang serupa. 


\section{HASIL DAN PEMBAHASAN}

\section{A. Gambaran Umum}

Rumah susun sewa di kecamatan Mariso terletak di pinggiran Selatan kota Makassar, Indonesia (Gambar 1). Kawasan ini terdiri dari daerah kumuh seluas 32,40 Ha2 yang ditempati oleh 11.091orang (30\%).

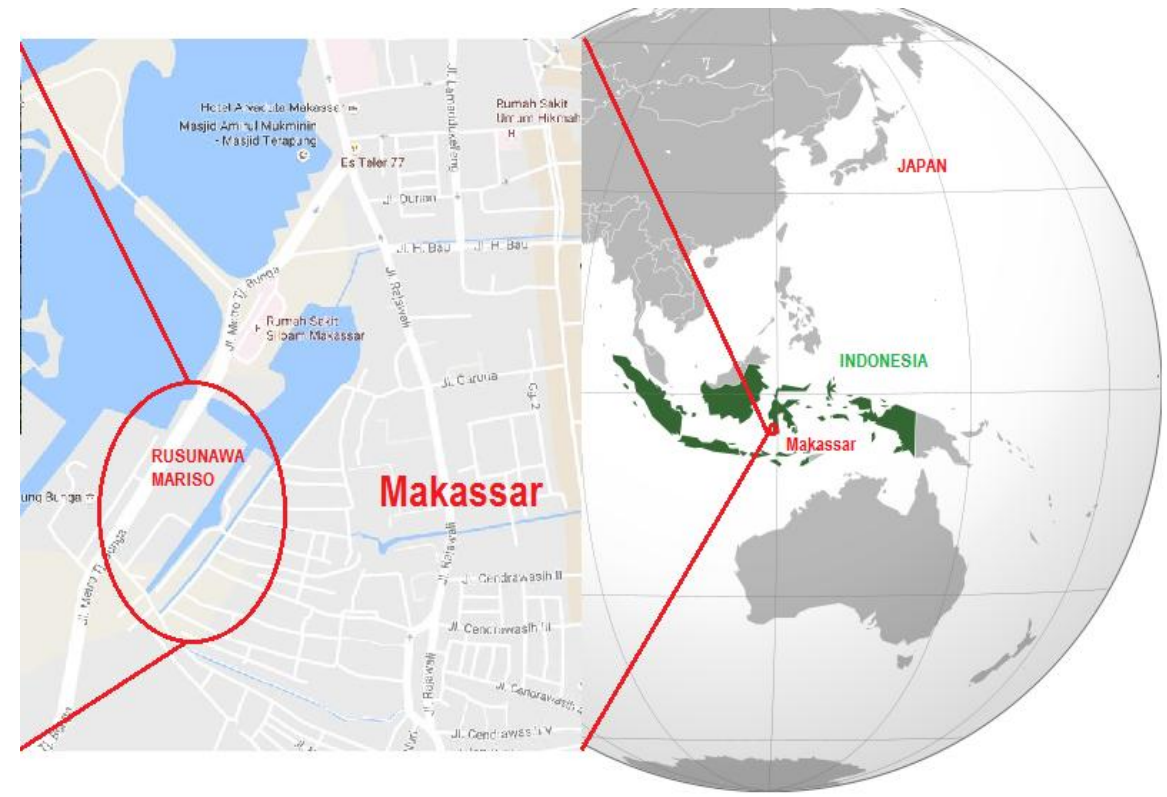

Gambar 1. Petalokasi Rumah Susun Kecamatan Mariso Sumber : www.google maps, 2017

Rumah susun sewa ini dibangun pada tahun 2005-2006 dan mulai dihuni sejak tahun 2007. Rumah susun ini dibangun untuk penghuni berpenghasilan rendah yang tinggal secara tidak teratur diwilayah sekitar area Kecamatan Mariso sekaligus untuk mengatasi kepadatan penduduk dan masalah kekumuhan yang ada di wilayah ini.Tempat tinggal vertikal ini awalnya dinominasikan untuk buruh harian, nelayan dan penduduk lokal yang menempati area di sekitar rumah susun yang direncanakan sebagai lokasi pembangunan untuk rumah susun sewa

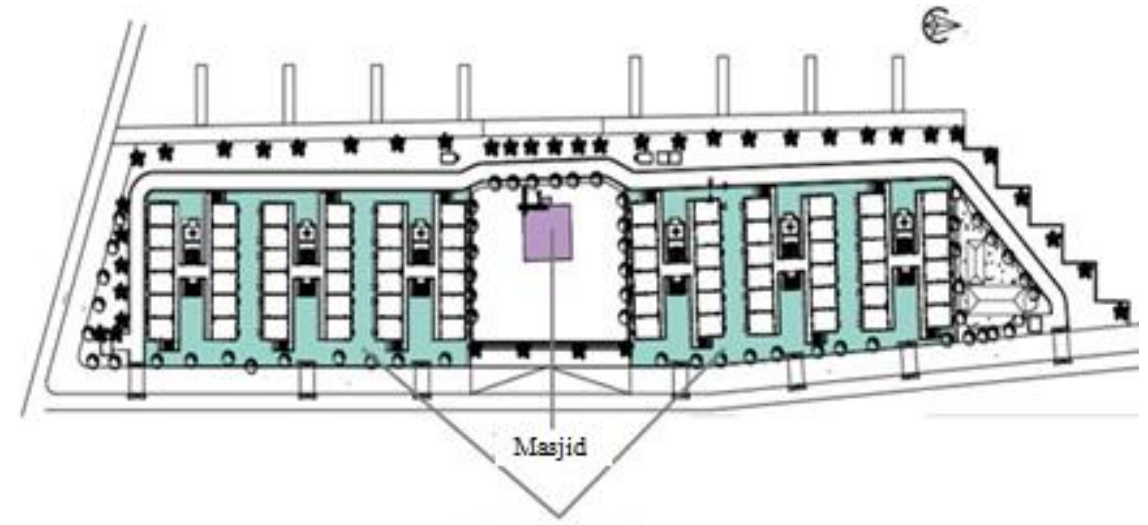

Gambar 2. Site Plan Rumah Susun Sewa Mariso Sumber : Data Survey, 2017

Rumah susun sewa di Mariso terdiri atas enam twin blok, dimana masing-masing blok ini memiliki dua bangunan saling berhadapan satu sama lain dengan corridor di depan setiap 
fasad unit perumahan seperti yang terlihat pada Gambar 3. Fasad merupakan elemen Arsitektur terpenting yang mampu menyuarakan fungsi dan makna sebuah bangunan membicarakan wajah sebuah bangunan (Marwati and Ikrama 2018). Kedua unit bangunan ini dihubungkan oleh tangga utama sebagai interkoneksi pada setiap lantai hingga lantai dasar. Terdapat lima lantai di setiap bangunan dan 48 unit hunian di setiap blok membuat total unit di rumah susun sewa adalah 288 unit dengan luas setiap unit hunian adalah $24 \mathrm{~m} 2$ (type 24) (gambar 2). Di setiap lantai rumah, ada fasilitassirkulasi seperti koridor, tangga utama, tangga darurat dan ruang komunal sebagai tempat pertemuan (Gambar 3).

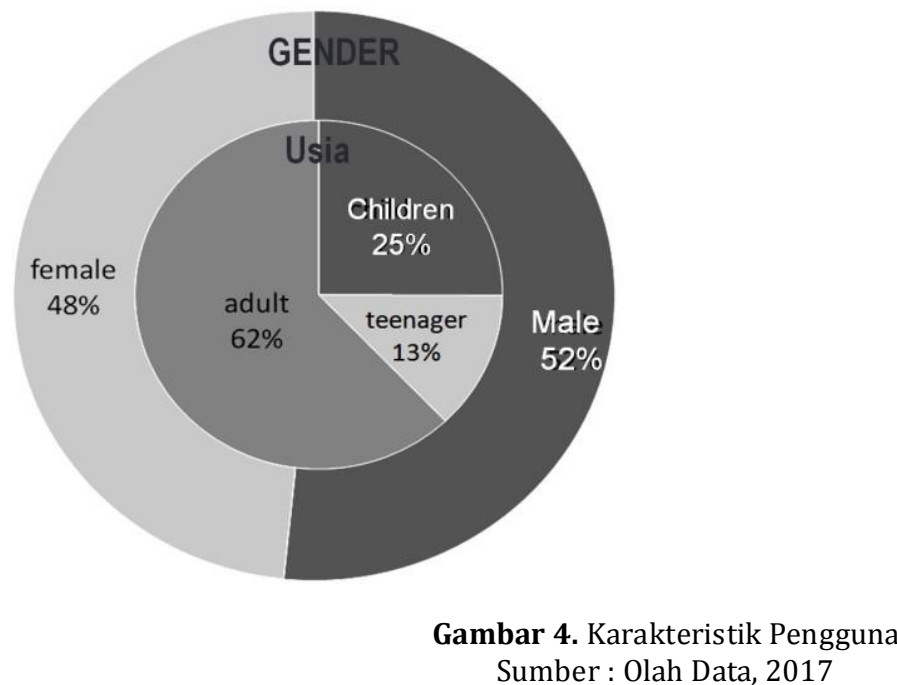

Fasilitas umum yang ada di wilayah rumah susun sewa adalah masjid, tempat sampah dan ruang terbuka didalam rumah susun sewa seluas sekitar $6000 \mathrm{~m} 2$ serta sebuah unit perawatan kesehatan anak (posyandu), namun pemanfaatan fasilitas ini tidak terbatas pada penghuni rumah susun, tapi semua komunitas distrik Mariso. Sebagai penghuni rumah susun sewa, mereka dibebankan membayar biaya sewa bulanan yang dianggap terjangkau untuk pendapatan mereka. Biaya sewa bulanan ditentukan berdasarkan level lantai. Semakin tinggi posisi unit huniannya, maka harganya lebih murah; Rp $150.000 \sim$ Rp. 75.000 untuk lantai 1 hingga lantai 4, berturut-turut berkurang sebesar Rp. 25.000 setiap naik ketinggian satu lantai.

\section{B. Karakteristik Pengguna Rumah Susun Sewa}

Berdasarkan data saat survey, jumlah pengguna rumah susun sewa adalah 942 orang. Terdistribusi dimasing-masing unit rumah berkisar 1-10 anggota. Ada juga unit perumahan tidak berpenghuni $(0.4 \%)$ karena berbagai alasan. Jumlah penduduk di perumahan susun sewa Mariso terbagi menjadi 3 kelompok umur berdasarkan jenis kelaminnya, yaitu anakanak ( $<12$ tahun anak laki-laki / perempuan) adalah 236; remaja (11 19 tahun laki-laki / perempuan) adalah 121; dan orang dewasa (> 20tahun laki-laki / perempuan) adalah 585; sedangkan distribusi gender adalah 485 laki-laki dan 457 perempuan, seperti yang ditunjukkan pada gambar4. 
Karakteristik penghuni berdasarkan pekerjaan, dibagi menjadi 5 kelompok yaitu; 1) Karyawan (bekerja untuk perusahaan swasta, pegawai negeri, keamanan, dan orang lain yang memiliki gaji tetap bulanan) adalah 115 orang; 2), Wiraswasta (bekerja sebagai pengusaha, pedagang / pedagang, supir, pengrajin, penjualan, dll) adalah 70 orang; 3) Pekerja harian (pekerjaan informal sepertipengendara becak, pengumpul sampah, pekerja konstruksi, dll tanpa penghasilan harian tetap)adalah 220 orang; 4) Orang lain (mahasiswa / mahasiswa, relawan, dll) adalah 231 orang; dan 5) Pengangguran (penduduk tanpa penghasilan, seperti istri rumah, anak-anak, pensiunan, dll) adalah 306 orang.
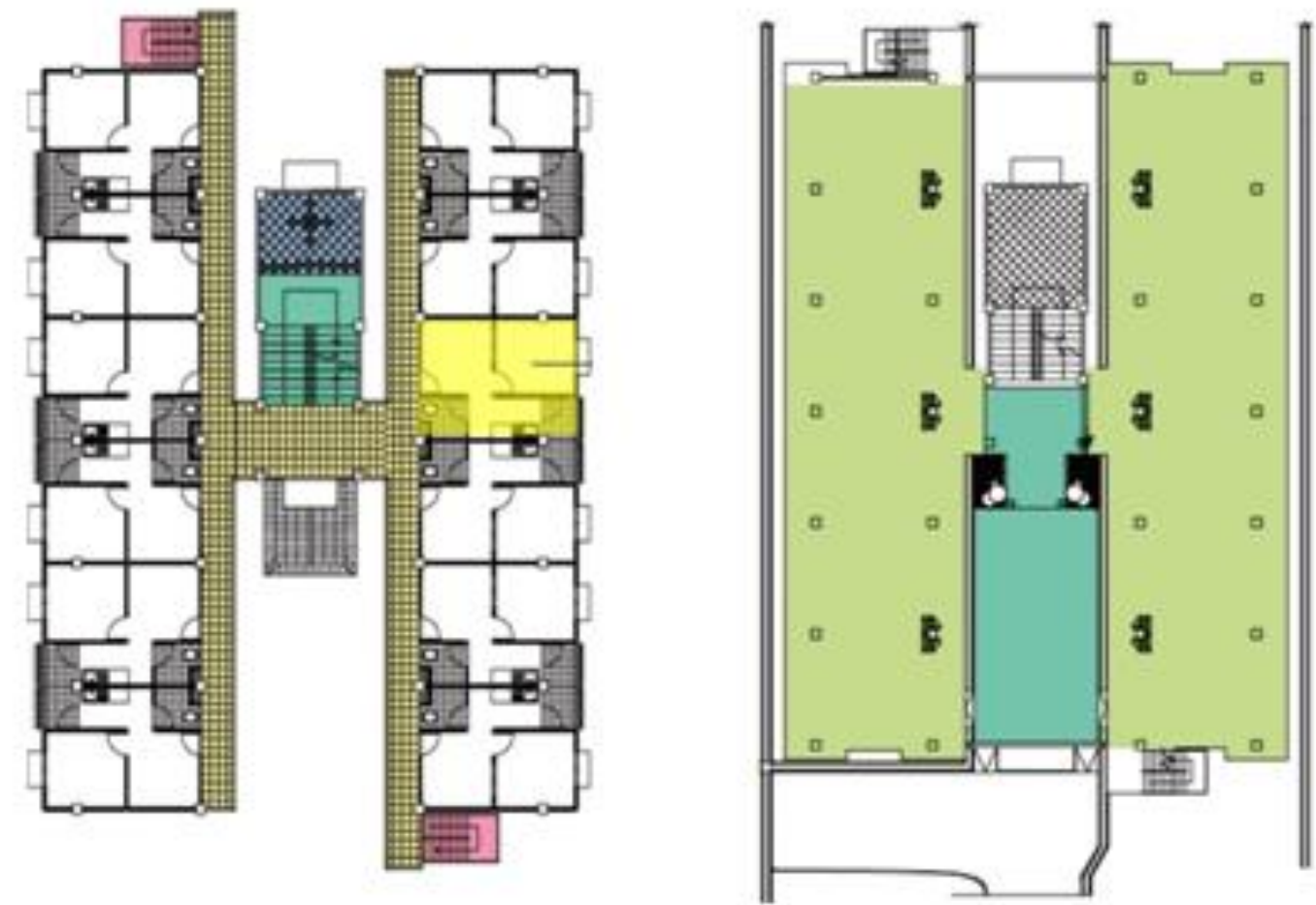

Gambar 5. Denah Typical Rumah Susun Sewa Mariso Sumber: Data Survey 2017

\section{Aktivitas dan Pengguna di Ruang Publik di Rumah Susun Sewa}

Berdasarkan hasil penelitian di lapangan, jenis aktivitas yang terdapat pada ruang-ruang publik sebanyak 31 jenis kegiatan, dimana setiap aktivitas ini dikelompokkan menjadi 6 jenis aktivitas utama yang terdiri atas aktivitas privat, aktivitas sosial, aktivitas ekonomi, aktivitas religi (keagamaan), aktivitas pendukung dan aktivitas berpindah (mobile). Aktivitas religi dan aktivitas berpindah merupakan aktivitas yang dianggap rutin dan dilakukan seperti keluar masuk rumah, berpindah dari satu tempat ke tempat yang lain di ruang public telah sesuai peruntukkannya sehingga dianggap wajar dan tidak dilakukan trace untuk hal itu.

Kegiatan Private adalah kegiatan yang dilakukan di dalam unit hunian secara pribadi/bersifat private untuk kepentingan keluarga, seperti memasak atau memasak, makan, berbaring atau tidur, mengeringkan / menggantung pakaian, membaca atau menulis, duduk diam atau saat berbicara dan merawat anak-anak. 
Kegiatan sosial adalah kegiatan yang dilakukan baik oleh penghuni atau pengguna lainnya yang dilakukan di ruang publik seperti di ruang komunal. Kegiatan ini termasuk antara lain berdiri diam, berdiri sambil ngobrol, bermain, berkumpul, membersihkan area publik, dan lain lain.



Gambar 6. Karakteristik Aktivitas

Sumber : Data Survey, 2017

Kegiatan ekonomi adalah usaha yang dilakukan untuk mendukung pendapatan keluarga karena pada unit hunian terdapat unit kegiatan ekonomi terkecil. Kegiatan yang dimaksud antara lain seperti menjual makanan, membeli dan menjual barang kebutuhan sehari-hari, memelihara tanaman atau hewan peliharaan (ayam, burung dan hewan lainnya) atau kegiatan lainnya yang diharapkan bisa menghasilkan uang.

Kegiatan pendukung ialah golongan kegiatan bukan kegiatan utama namun dapat mendukung kegiatan lain, seperti olahraga, membuang sampah, memperbaiki atau merawat kendaraan pribadi seperti sepeda, becak, motor, mobil atau gerobak.

Berdasarkan penelusuran rekam jejak ke objek observasi selama 4 hari yang terlibat dalam penelitian ini, tercatat terdapat 7868 kegiatan. Kegiatan berpindah adalah kelompok kegiatan yang paling sering dilakukan di semua ruang publik rumah susun sewa, tercatat sebanyak 4334 kali dalam 4 hari penelusuran. Kelompok aktivitas dominan berikutnya adalah aktivitas sosial yang tercatat 1631 kali. Kelompok ini hampir sebanding dengan kegiatan pribadi yang mencapai1.469 kali (Gambar 5). Tindakan kegiatan pribadi di ruang publik didasarkan pada berbagai alasan keterbatasan unit rumah, sehingga penduduk terkadang melakukan aktivitas pribadi mereka di luar rumah seperti memasak, menyiapkan makanan atau bahkan tidur. Kegiatan gantung pakaian atau pengeringan selalu dilakukan di luar rumah 
oleh hampir semua penduduk, meski masing-masing unit telah memiliki balkon (panjang 0,8 $\mathrm{m}$ dengan lebar 1,5 m), namun kenyataannya tetap di lakukan di depan unit hunian mereka sendiri meskipun dengan konsekuensi tak terduga seperti resiko kehilangan / dicuri kapan saja.

\section{Preferensi Aktivitas dan Lokasi Aktivitas Pengguna}

Terdapat delapan lokasi yang ditujukan untuk umum di rumah susun sewa yang dikategorikan menjadi: ruang terbuka public dan ruang terbuka khusus untuk penghuni. Ruang publik yang dekat sebagian besar bersatu di dalam blok Rumah susun sewa, yaitu koridor, tangga utama, ruang komunal, tangga darurat, pintu masuk gedung dan area parkir. Sedangkan ruang publik terbuka terletak di sekitar rumah susun sewa, yaitu masjid dan open space di sekitarnya.

Fungsi utama setiap ruang publik Rumah susun sewa telah ditentukan sebagai berikut: koridor untuk akses warga ke perumahan unit mereka dengan luas $1 \mathrm{~m}$ dan panjang $27 \mathrm{~m}$; terletak di 2 sisi setiap tingkat bangunan, dibuat seluas $68 \mathrm{~m} 2$. Kedua koridor tersebut dilekatkan pada koridor interkoneksi ke tangga utama yang berfungsi terutama untuk mendukung aksesibilitas warga. Tangga utama yang berada di tengah bangunan berukuran $3.6 \mathrm{~m} \times 4.2 \mathrm{~m}$ ini lebar dengan ruang komunal tambahan di setiap tingkat perbatasan.
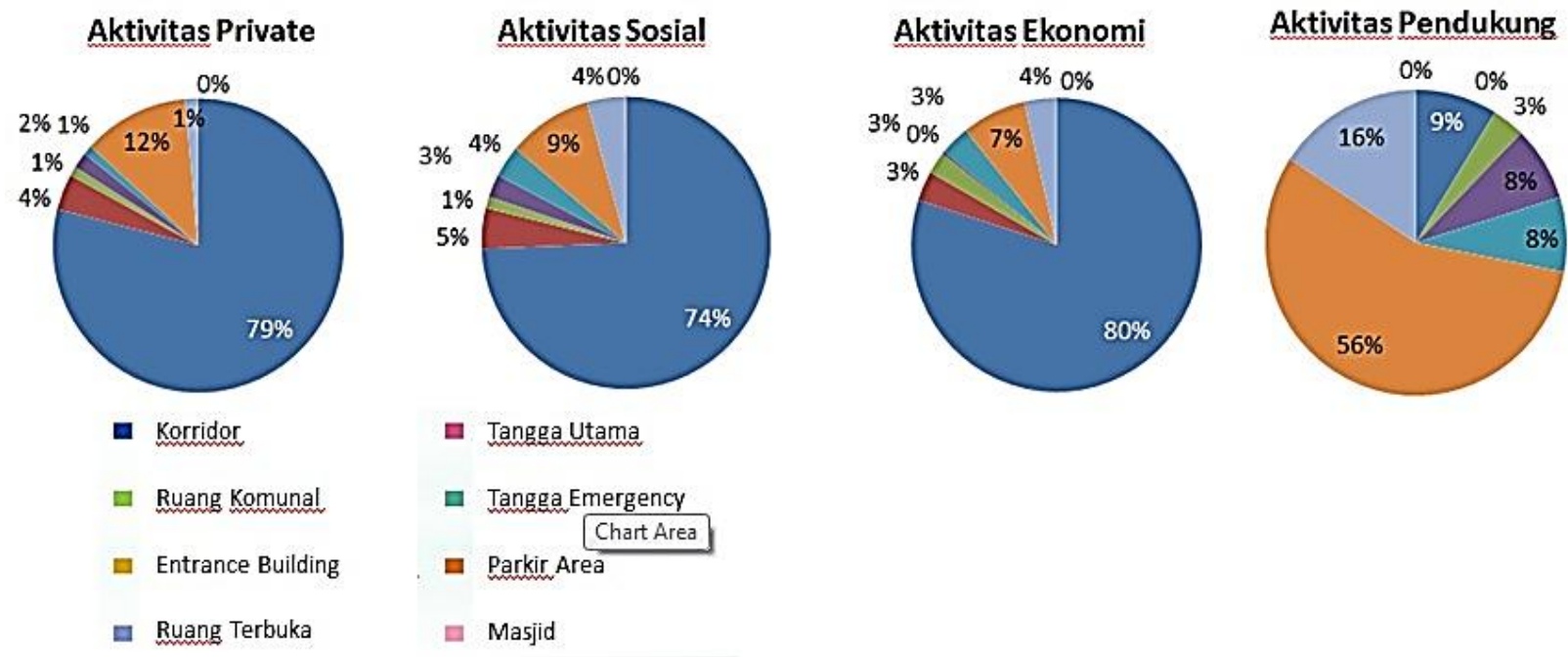

Gambar 7. Grup Activitas Sumber : Olah data, 2017

Di kedua sisi bangunan, terdapat tangga darurat dengan lebar $0.6 \mathrm{~m}$. Di lantai dasar, terletak pintu masuk bangunan dengan luas sekitar $52 \mathrm{~m}^{2}$. Tempat parkir juga berada di lantai dasar dengan luas $170 \mathrm{~m}^{2}$.

Secara keseluruhan dari pengamatan objek yang tidak diketahui, ditemukan bahwa total aktivitas yang sering dilakukan di ruang publik dilakukan oleh anak-anak sekitar $32 \%$, remaja $28 \%$ dan orang dewasa sebesar $40 \%$. Sedangkan menurut jenis kelamin ditemukan total aktivitas wanita sekitar $61 \%$ dan laki-laki hanya $39 \%$. 
Di antara fasilitas umum yang ada, terdapat beberapa fasilitas yang dimanfaatkan tidak optimal, sementara beberapa lainnya sangat fungsional dan cenderung melebihi fungsi aslinya.Selama pengamatan, fasilitas umum yang paling banyak dinikmati oleh semua objek survei adalah koridor dengan rata-rata sebesar 61\% karena aksesibilitas (Gambar 6). Koridor merupakan ruang publik yang paling mudah di capai warga, tepat di depan rumah unit, sehingga sangat strategis untuk kegiatan. Meski dengan koridornya relatif sempit (sekitar 1 meter), namun tetap dimanfaatkan sebagai ruang pribadi dengan menempatkan kursi-kursi pribadi / bale-bale atau pot tanaman secara permanen di sepanjang koridor. Kondisi ini membuat koridor menjadi ruang publik yang paling banyak dimanfaatkan, diikuti oleh ruang terbuka dan area parkir masing- masing $21 \%$ dan $6 \%$. Koridor juga berfungsi sebagai ruang publik untuk melakukan aktivitas perdagangan oleh beberapa penghuni, baik sementara maupun permanen. Sementara itu, fasilitas umum yang dianggap kurang bermanfaat adalah tangga darurat, yang dimanfaatkan sebanyak 4\% terlepas dari beberapa di antaranya rusak, sedikit lebih sering daripada pemanfaatan ruang masjid dan komunal, keduanya sebesar $1 \%$.

\section{KESIMPULAN}

Observasi rinci terhadap delapan wilayah studi dengan faktor pengguna, tempat dan jenis kegiatan; Studi dapat disimpulkan sebagai berikut: Aspek sosial; Meskipun penduduk memiliki berbagai latar belakang budaya (heterogen), namun berhasil mengembangkan rasa kekerabatan yang kuat dalam sistem antar masyarakat yang terbuka, tidak menciptakan batasan waktu dan ruang pada interaksi mereka sehari-hari. Penduduk Rumah susun sewa yang berpenghasilan rendah lebih memilih untuk tidak hidup dalam gaya hidup formal. Mereka menikmati melakukan kegiatan pribadi bersama dan dalam kasus tertentu melakukan intervensi ruang publik untuk kepentingan pribadi.

Konsep koridor didefinisikan ulang tidak hanya untuk ruang gerak tetapi juga untuk ruang berbasis aktivitas. Sebagai area transisi sebelum memasuki unit rumah, ia mengakomodasi aktivitas pribadi dan sosial dan berubah menjadi tempat paling favorit di rumah susun sewa.

Ruang yang paling tidak dimanfaatkan adalah ruang komunal. Lingkungan yang tidak memadai dengan dinding sekitarnya yang sangat besar, pemandangan yang sangat terbatas dan posisi split level menjadikan ruangan ini tidak nyaman untuk dikunjungi. Fasilitas tertentu seperti untuk mendukung kegiatan ekonomi tidak tersedia, memaksa warga untuk menyalahgunakan ruang lain berdasarkan intuisi mereka sendiri dan kurang diatur, kebanyakan di koridor dan area lantai dasar.

Pendekatan berbasis masyarakat seperti perilaku diperlukan tidak hanya untuk mengeksplorasi dan memecahkan masalah perumahan, tapi juga bisa memperbaiki kondisi sosial dan ekonomi masyarakat melalui mobilisasi usaha dan keterampilan yang ada. 


\section{DAFTAR REFERENSI}

Carr, Stephen, Carr Stephen, Mark Francis, Leanne G Rivlin, and Andrew M Stone. 1992. Public Space. Cambridge University Press.

Holland, Caroline, Andrew Clark, Jeanne Katz, and Sheila Peace. 2007. Social Interactions in Urban Public Places. Policy Press.

Lumbantoruan, Robinhot Jeremia, Muhammad Faqih, and I Gusti Ngurah Antaryama. 2010. "Study of Room Utilization Post Occupancy in Suka Ramai Walk up Flat." In National Seminar on Urban Development Housing Settlement.

Marwati, Marwati, and Ikrama Ikrama. 2018. "Identifikasi Fungsi Dan Fasad Pecinan Pada Bangunan Di Ruas Jalan Sulawesi Makassar." Nature: National Academic Journal of Architecture 5 (2):135-42.

Prayitno, Budi. 1999. "Low Cost Rental Development in Indonesian Large CitiesTransformation from Traditional Kampung to Multistory Housing." Journal of Architecture Planning and Environmental Engineering 517. AIJ:243-50.

Said, Ratriana, and Alfiah Alfiah. 2017. "Teritorialitas Pada Ruang Publik Dan Semi Publik Di Rumah Susun (Studi Kasus: Rumah Susun Kecamatan Mariso Makassar)." Nature: National Academic Journal of Architecture 4 (2):128-37.

Siregar, Mohammad Jehansyah. 2013. "Sistem Penyediaan Perumahan." Kementerian Perumahan Rakyat. Kebutuhan Rumah Di Indonesia. 